\title{
Image of China in Afghanistan News Discourses: A Corpus-Based Critical Discourse Analysis
}

\author{
Sakhidad Sangeen ${ }^{1}$ \\ ${ }^{1}$ School of Foreign Languages, Shanghai Jiao Tong University, China, 800, Dongchuan RD. Minhang District, \\ Shanghai, China \\ Corrspondence: Sakhidad Sangeen, School of Foreign Languages, Shanghai Jiao Tong University, China, 800, \\ Dongchuan RD. Minhang District, Shanghai, China. E-mail: sakhidad.sangeen2014@gmail.com or \\ ssangeen213@gmail.com
}

Received: November 29, 2019 Accepted: January 3, 2020 Online Published: February 5, 2020

doi:10.5539/ijel.v10n2p217

URL: https://doi.org/10.5539/ijel.v10n2p217

\begin{abstract}
Afghanistan and China have a long credible history and reliable relationship. Afghanistan-China's friendship has been verified to be the model of cooperation between two neighboring countries. Both states have strong historical, cultural, social, economic, and political relations together. The relationship emerged in front of the world in 1955, when both the countries signed an economic treaty, known as the "Treaty of Economic and Technical Cooperation." The study aims to investigate the image of China in the Outlook English newspaper of Afghanistan, whereas China's recent development in trade and the economic rise around the globe has given new birth to the cooperativeness between both the countries. The current trade has reached up to $\$ 700$ million between both the countries. Thus the study identifies the facts from the corpus-based analysis that the frequency of economic relations between Afghanistan and China has risen due to a significant trust and friendly relation with each other. Moreover, the success in economic trade depends on the positive perspective of an excellent historical background and political relationship in the history of one's country in another. Both countries' good historical friendships reveal a significant positive image of China in Afghanistan's Outlook English newspaper. The occurrences of development, China, cooperation, economic and industrial cooperation reveal China's interest and friendly relations moving towards Afghanistan in particular. Therefore, such engagements of China with Afghanistan will bring economic development and make a better security situation in Afghanistan.
\end{abstract}

Keywords: corpus-based, critical discourse analysis, China image, Afghanistan newspaper

\section{Introduction}

Afghanistan, as an important geopolitical neighbor of China, has many glaring peculiarities, including; strategic, political, economic, and geographical location. However, the global security environment is rapidly changing; there is a need for cooperation not only between Afghanistan and China but also for all those countries which need and demand regional harmony and peace based on mutual sovereignty and respect. Furthermore, China and Afghanistan have had a close, genuinely stable, an inseparable relationship for long ago. Afghanistan, due to its unique geographic location, cultural, tradition, political, and positive historical background with China, plays an essential role in different aspects. Afghanistan is one of the richest countries based on the different kinds of resources; on the other side, China is an industrial country that needs as much as raw resources for its industrial products. Therefore, Afghanistan plays a key role in different perspectives like; raw mineral, copper mine, oil, gas, and many other vital resources among the Asian countries.

Furthermore, media plays a pivotal role in creating the ideological construction of an image, identity, and, more specifically, media trial the people of countries behavior as well. Morever, Tolson (1996) states, the news is a continuously updated and, continuous text, which has not a conclusion and punctuates a society on a 'repeated and scheduled regulation' (p. 18). News is often criticized for misleading its audiences. Hence, the news is not a 'value-free reflection of "facts"' (Fowler, 1991).

Newspapers have been an active, authentic source and playing their role in presenting the facets and events in the world. English newspapers are the best option for focusing on China's image in Afghanistan media. China, due to its economic stability in the world economy, has gained much popularity. According to van Dijk (1998), he 
argued that through a critical viewpoint, some principles are 'superior' to others when the public project requires an attempt to achieve equity. The universal economic evaluation report of 2016-2017 showed that the international community has more assurance in China's economic prospects. Similarly, the recent study of foreign experts found that China's economic improvement contributes to global economic development.

Therefore, China plans to promote its commercial projects in other countries in order to have a stronger economy and trade. In addition, other countries receive advantages from China's economic development. Therefore, China's economic improvement enhances China to have a stronger military too. Besides that, the other relatively good reaction of China's economic improvement influences on China's economic ranks. Now China is a second economic power in the world. Moreover, according to the global evaluation report, China is going to be a robust economic rival of the USA in the world.

Furthermore, in the recent few decades, China has appeared as her enormous economic power in the world. For these reasons, China has started collaboration in terms of business, trade, and a mega economic project known as the Belt and Road Initiative. Additionally, focusing on the view of Chain's image in Afghanistan, the study focuses on a country where internet access and the use of media and reading newspapers text are rapidly growing. In recent years, media and newspapers in Afghanistan society have significantly spread and developed in many ways. Therefore, the study argues in a clear perspective on the image of China in the Afghanistan English newspaper. Moreover, the significance of conducting this research determines a generic reflection of China's image in the Afghanistan Outlook English newspaper. Moreover, by conducting this research, the researcher examines how the Afghanistan English newspaper reflects the China-image to Afghanistan community.

Furthermore, public image is the product of composite historical procedures including culture, social realities, diplomatic relationship, global policies, economic durability as well as, symbolic representation in the mass media (Peng, 2004; et al., 2019). Primarily the image of a nation has been shaped by mass media and connected to how media selection expresses and delivers news regarding a social situation. Furthermore, national image, also named national categorizes, to conceptualize as a generalized and brief profile of the nation or its people (Huang \& Leung, 2005). The last survey of national picture in the media has concentrated on how an object-picture is expressed in a mass average, and how separately realizes an entity-nation in public opinion (Lippmann, 1945; Buchanan \& Cantril, 1953). According to Lippmann's ideas regarding images, of a nation, the image is in the brain of everyone at a conglomeration step (Crespi, 1961). Furthermore, Boulding (1966) indicated that the picture is our subjective education toward humanity. Thus, this picture greatly regulates our actions.

\section{Previous Studies of Critical Discourse Analysis and Corpus Linguistics}

Critical Discourse Analysis (CDA) can be defined as "discourse analysis with Critical attitude," which relates to "exact and normally extended attitude of social reaction that takes a linguistics shape or a partial linguistics style" (Fairclough \& Wodak, 1997, p. 258). According to Mautner (2009), there are at least three essential principles in CDA (1) a discourse of establishing community and tradition; (2) secure connection in discursive and (3) CDA has an engagement to study discourse covering as an essential social issue. In short, CDA goals are used for preparing explanations and interpretations of social phenomena from discourse eyes. Moreover, one central discussion in textual discourse investigation over the last decade concerned to the corpus linguistics application in discourse analysis. The following interpretive culture of language analysis CDA tends to be quantitative investigation management, which is not innately attached to corpus linguistics.

Baker (2006) clarifies different methods for what an investigator can be prejudiced; for instance, not desiring to admit one's viewpoint and perceptive prejudice relating procedure info, searching proof which cooperates one's demand and disregarding evidence which does not (p. 11). Moreover, via, utilizing the plenty of texts, an investigator can understand the progressive character of discourse; in place of concentrating some text and possibly miss abroad sample. Through utilizing a corpus, the investigator responsible for supervising the visibility of an exact word, expression, or construction in pertinence to a standard" (Tognini-Bonelli, 2004, p. 19; et al., 2019). Baker (2006) Demonstrated that the use of understanding corpus discloses the awareness of its sample. For instance, connecting a specific type of public group, age range, outstanding racial team, the political condition is not accessible through the public network (p. 14).

Furthermore, a variation of discourse can be recognized by utilizing historical corpus, corpora comprising texts through several terms, and measuring of occurrences the contexts. For example, where a specific sample is reflecting, how, and where it opens out (Orpin, 2005, p. 57) when the vocabulary has changed technically, it utilized much popular, by various teams, or has accumulated via a metaphorical function. However, Baker does not claim that corpus linguistics must be the solitary approximate utilized by the investigator. So, in replacing 
individual defendants, the triangulated comparative corpus linguistics is being used in composition with consummating methodologies and ideas to propose a complete resolution of a linguistics event (Quratulain, 2019). Corpus can be recognized in the resolution of public discourses investigated usage with elements of corpus linguistics of critical discourse resolution or sociological methods.

Moreover, this subdivision of corpus linguistics investigation utilizes a corpus but seems to sample, it concerned with "variability, struggle, and change" (Fairclough, 1992, p. 36) utilizes opinions that drawn through critical discourse resolution. It also consists of investigation like; Leech and Fallon's (1992) analogy among American and British texts and their examination in penetration of several cultures, histories, and juridical order on the language as well as (Teubert's, 2007) penetration beyond discourses and change in notion on a corpus. Furthermore, the Vatican provides the documentary evidence, especially the keywords job and possessions in their connection to the idea of ordinary law' and human being rights' in Catholic public doctrine.

Influential CDA literature (e.g., Fairclough, 1995; Fairclough \& Wodak, 1997; van Dijk, 1988) has mainly accepted self- allured investigation data with an emphasis on the importance of data credibility and contextual awareness regard collected discourse resource. As an outcome, the decontextualized language information in many early constituted corpora (e.g., the American National Corpus) and British National Corpus lacks contextual data needed for in-depth CDA. Furthermore, more discourse and different scholars have discussed that corpus linguistics methods are unsuitable for discourse studies due to the battle among "bottom-up" and "top-down" processes of analysis (Rafique et al., 2018). For example, (Swales, 2002) mentioned that translating type and discourse construction seriously requires a "top-down" process for translating macrostructures of texts, which makes much corpus linguistics methods (e.g., lexical/phrasal frequency and concordance) discordant with type and discourse studies due to their bottom-up processes of analysis and the lack of contextual attentiveness.

Hardt-Mautner (1995), more recently, Baker et al. (2008) and Baker (2010) have begun to call for an integrated approach in an attempt to bring corpus linguistics and CDA together stimulate a dialogue between quantitative and qualitative approaches. Whenever final improvements in corpus linguistics have presented a favorable perspective for corpus-driven Critical discourse studies, in the creation of corpus linguistics software (e.g., WordSmith Tools 6.0) permits for many and fast drawing out of a particular basic unit of the lexicon language and phrases to correct their sentential contexts. The fast-expanding of the internet has also changed the condition of online text accessibility. In specific, traditional newspapers have finally been digitized, which makes accessible materials collection and corpus assembling procedures. According Flowerdew (2005), with strict investigation plans, corpus linguistics methods can be an efficient implementation for discourse and genre investigation.

Furthermore, conclusive studies (e.g., Baker et al., 2008; Prentice \& Hardie, 2009; Salama, 2011) have recommended different vital benefits of using corpus-driven methods in Critical discourse studies, for development of investigation credibility through the progressive impression of discourse. Concisely, there is a growing tendency in corpus linguistics to look to recommend that corpus-aided Critical discourse analysis, becomes much familiar soon. According to the majority of these studies, it significantly concentrates base on linguistically text analysis from a different perspective of China's image through the Afghanistan Outlook English newspaper. Therefore, this study shows China's developments as an economic power: in the case of the durable economic power of the region in the twenty-first century, which plays a vital economic role in the world.

The study focuses on the following research questions.

How China is portrayed in the selected Afghanistan English newspaper?

Furthermore, what are the standard and robust keywords used by the selected newspapers for the China-Afghanistan friendship image?

\section{Data and Method}

The study follows both qualitative and quantitative approaches. The CORPUS tool is applied to analyze the data for the statistical representation of results through concordances, collocations, and frequency of keywords. The data for the study is taken from the Afghanistan English newspaper (Afghanistan official website of 'Outlook' from the year of 2016 to 2018). Data comprises newspaper texts, which is taken from official websites of selected English newspaper 'Outlook' in Afghanistan for three consecutive years (2016-2018). Moreover, referring to a related topic on several academic websites enable us to reach for many other similar useful topics. Thus, those topics will help to support our idea regarding to the real issues during the data collections.

By addressing the mixed-method of research, this study will try to present and provide an integrated perspective and full understanding of the research topic in the Afghanistan Outlook English newspaper text. The data 
contains of a large corpus of 195295-words tokens and 10834-words types. The study used a theoretical framework three-dimensional models of critical discourse analysis proposed by Norman Fairclough (1989) and merged it with the corpus linguistics. Corpus linguistics assists in providing substantial results based on statistical representation out of the entire data, whereas the qualitative analysis was made through the selected speeches of Chinese and Afghanistanian representatives in the light of the three-dimension model.

\section{Results and Discussions}

The present study focuses on the image of China in Afghanistan English newspaper, for which specific keywords in context have been searched from the corpus through the AntConc version 3.4 to identify the position of China in Afghanistan. However, the results reveal that the occurrence of China is significantly higher than the United States, whereas the words such as 'development,' cooperation,' 'bilateral' show the positive image of China, and Chinese interest in Afghanistan and their interest is based on their mutual-cooperation. Table 1 shows the understanding of the China Afghanistan relationship in detail and friendly cooperation. 'The high-quality of responsibility an in-depth analysis of the precise keywords such as development, friendship, Pakistan, US, are reliable with the CDA framework: which groups and individuals are represented in the newspapers, how writers or columnist ideologically construct the particular image of people, countries, and individuals

Table 1. Frequencies of keywords in context

\begin{tabular}{ll}
\hline Keywords & Frequency \\
\hline China & 3964 \\
Cooperation & 1004 \\
Development & 574 \\
Bilateral & 500 \\
Friendship & 400 \\
Afghanistan and China & 550 \\
Infrastructure & 91 \\
US & 158 \\
Pakistan & 256 \\
\hline
\end{tabular}

Concordance lines analyze the patterns occurring in the data. It helps in analyzing the contextual information, a portrayal of once image embedded in the data. However, the section analyses the concordances of the portrayal of China in Afghanistan English Outlook newspaper, selected concordances based on random selection have been analyzed in detail. The study analyses the data and searches the word 'China' in the entire corpus, in the beginning, the complete concordance lines that appeared in the corpus associated with China are 3964 out of the entire corpus of 1244098. China proves to be the most occurring pattern in the data.

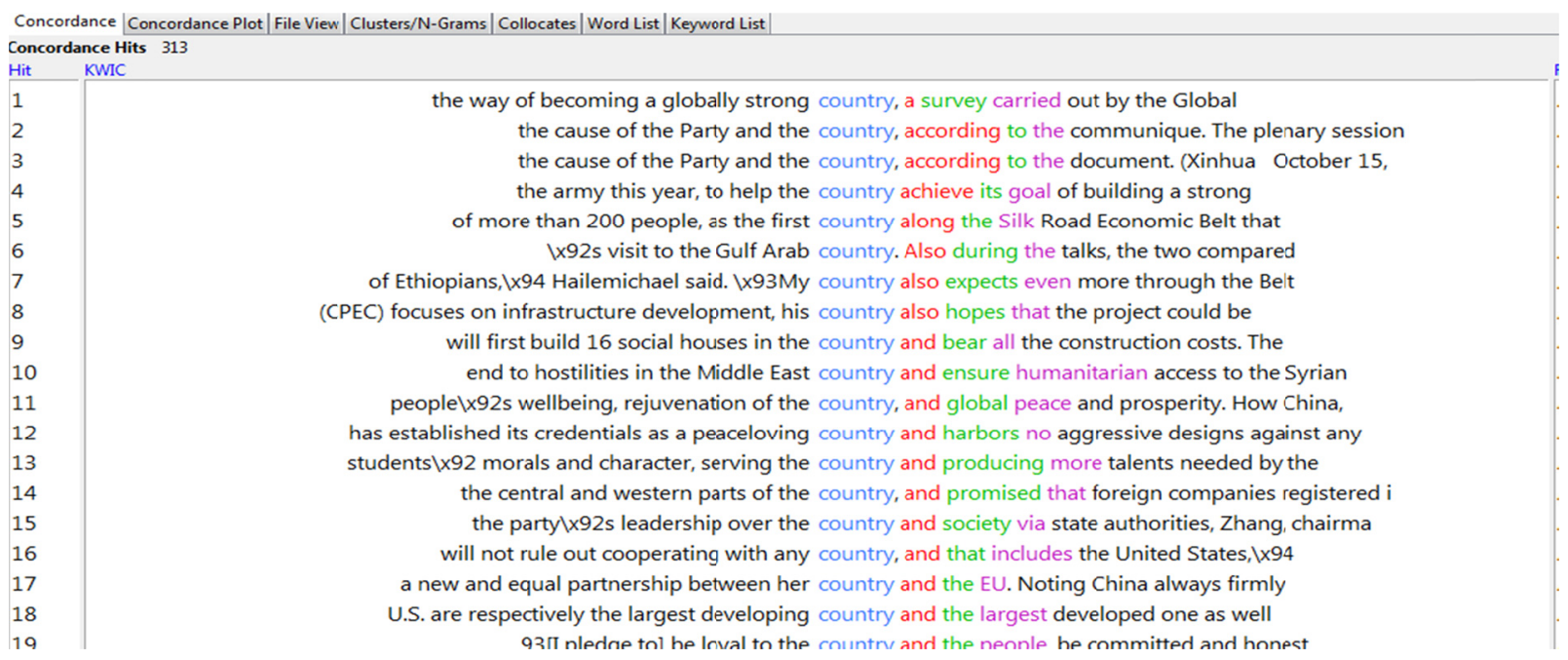

Concordance 1. Concordance of keyword search 'Country' demonstrates the occurrence of associated words with country 
The word country randomly was searched in the data; a total of 313 concordances appeared in the data. Concordance fig 1 shows the contextual analysis of the words used in the relation of the country. The analysis indicates that words such as infrastructure, well-being, Silk Road, construction, and development reveal that China has a very positive image in the newspaper of Afghanistan.

\begin{tabular}{|c|c|c|}
\hline 1 & X92s Zhuhai air show in southern China, a biannual event that showcases China|x92 & Afghanistan \\
\hline 2 & -year term of office starting from Jan. 1, 2017. China, a current member of the council whose & Afghanistan \\
\hline 3 & fghanistan/english/daily-outlook-afghanistan.html China a <ey Player in Future Innovative Technologies: & Afghanistan \\
\hline 4 & up his fruitful three-day visit in China. A more transparent and favorable cooperative mec & Afghanistan \\
\hline 5 & nstructive and results-oriented relationship with China, a senior U.S. State Department official & Afghanistan \\
\hline 6 & lateral ties, the Chinese minister added. Calling China a :rust-worthy strategic partner, the Bangladeshi & Afghanistan \\
\hline 7 & and capacity, the vice premier said. Calling China a :rustworthy friend of Iran, Zarif said & Afghanistan \\
\hline 8 & October 26,2017 Xi Vows to Deepen Reforms, Make China a 'x91 Leading Global Power|x92 BEIING - & Afghanistan \\
\hline 9 & Jinping pledged to deepen reforms to make China a 'x93leading global power|x94 by 2050 , & Afghanistan \\
\hline 10 & lack of transparency and information provided by China about violent incidents in China that the & Afghanistan \\
\hline 11 & as soon as possible, $1 \times 93$ Liu said. China abstained from the French-drafted resolution, whi & Afghanistan \\
\hline 12 & Engage in Joint Oil, Gas Projects with China ABU DHABI - Pakistan $1 \times 92$ s Petroleum and & Afghanistan \\
\hline 13 & Theresa Maylx 925 new move on China, according to a Sunday report by the & Afghanistan \\
\hline 14 & approach should no long be used against China, according to Article 15 of the accession protoco & Afghanistan \\
\hline 15 & 92 s code of conduct and corruption in China, according to the top anti-graft body & Afghanistan \\
\hline 16 & northwest to densely populated Henan in central China, according to the State Grid, Qinghai branch. & Afghanistan \\
\hline 17 & cutting off oil shipments to the North. China accounts for more than 90 percent of trade & Afghanistan \\
\hline 18 & 92s development.|x94 (Xinhua) October 15, 2018 China Acknowledges Pakistan|X92s \×91Outstanding Contri & Afghanistan \\
\hline 19 & $\mathrm{n}$ the future. (Monitoring Desk January 03, 2018 China Actively Meets Challenges of Climate Change in & Afghanistan \\
\hline 20 & in today $\times 92 \mathrm{~s}$ world, $\mathrm{X}$ i said China advocated the building of a community with & Afghanistan \\
\hline
\end{tabular}

Concordance 2. A full set of concordance lines of China express the repetition of China

The occurrence of 'China' is relatively more significant as compared to the random searches of the occurrence of any country in the corpus, which clearly shows the top debate is focused on the credibility of China in the infrastructure building, economic cooperation, and political stability in Afghanistan.

\begin{tabular}{|c|c|c|}
\hline \multicolumn{3}{|c|}{ 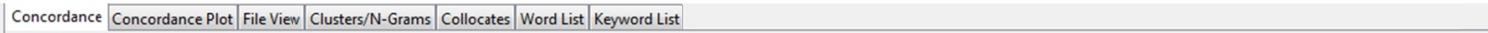 } \\
\hline \multicolumn{3}{|c|}{ Concordance Hits 3964} \\
\hline Hit & W.C & File \\
\hline 26 & also contributors. The foreign respondents ranked China after the US as the second country & Afghanistan \\
\hline 27 & River is the second longest river in China after the Yangtze River. It originates from & Afghanistan \\
\hline 28 & their country should maintain good relations with China. (Agencies) December 19, 2017 China is Playing & Afghanistan \\
\hline 29 & 92s clothes in Tajikistan are imported from China. (Agencies) June 22,2016 http://pknewspapers.com & Afghanistan \\
\hline 30 & China and Russia. (Reuters) June 22,2017 UK And China Agree Renewable Energy Deal LONDON - UK and & Afghanistan \\
\hline 31 & ters) October 13, 2018 Kyrgyzstan, Uzbekistan, China Agree to Co-Op on Road Transportation & Afghanistan \\
\hline 32 & ation $\backslash$ x94. (Xinhua September 27,2016 Australia, China Agree to Open Aviation Market CANBERRA - Austral & Afghanistan \\
\hline 33 & oost Financial Ties YOKOHAMA, Japan - Japan and China agreed to bolster economic and financial cooperat & Afghanistan \\
\hline 34 & Security of the CPEC ISLAMABAD - Pakistan and China agreed to ensure security of the China & Afghanistan \\
\hline 35 & confusion about what the U.S. and China agreed to in a tariff ceasefire. KEEPING & Afghanistan \\
\hline 36 & long-sought concession to the U.S., China agreed to label fentanyl, the deadly synthetic & Afghanistan \\
\hline 37 & QUESTIONS: Investor confidence in the U.S.- China agreement faltered after confusing and conflictin & Afghanistan \\
\hline 38 & about four hours. KCREAN PENINSULA NUCLEAR ISSUE China agrees the United Nations Security Council should & Afghanistan \\
\hline 39 & fluttering red flags, buses emblazoned with $\backslash \times 93$ China Aid \×94 logos and even a purpose- & Afghanistan \\
\hline 40 & luted are key issues. (Xinhua) September 23,2017 China Aims to Attract more Foreign Investment BEIING & Afghanistan \\
\hline 41 & Overseas Nuclear Power Units by 2030 BEUING - China aims to build 30 nuclear power units in & Afghanistan \\
\hline 42 & all of whom live in the countryside. China aims to eliminate poverty by 2020 when its 13 & Afghanistan \\
\hline 43 & ratio of oil consumption would peak at 2030. China aims to increase domestic crude oil output & Afghanistan \\
\hline
\end{tabular}

Concordance 3. A snapshot of a concordance of 'China*1 indicates the patterns featuring China and United Nations' role in bringing economic stability in Afghanistan 


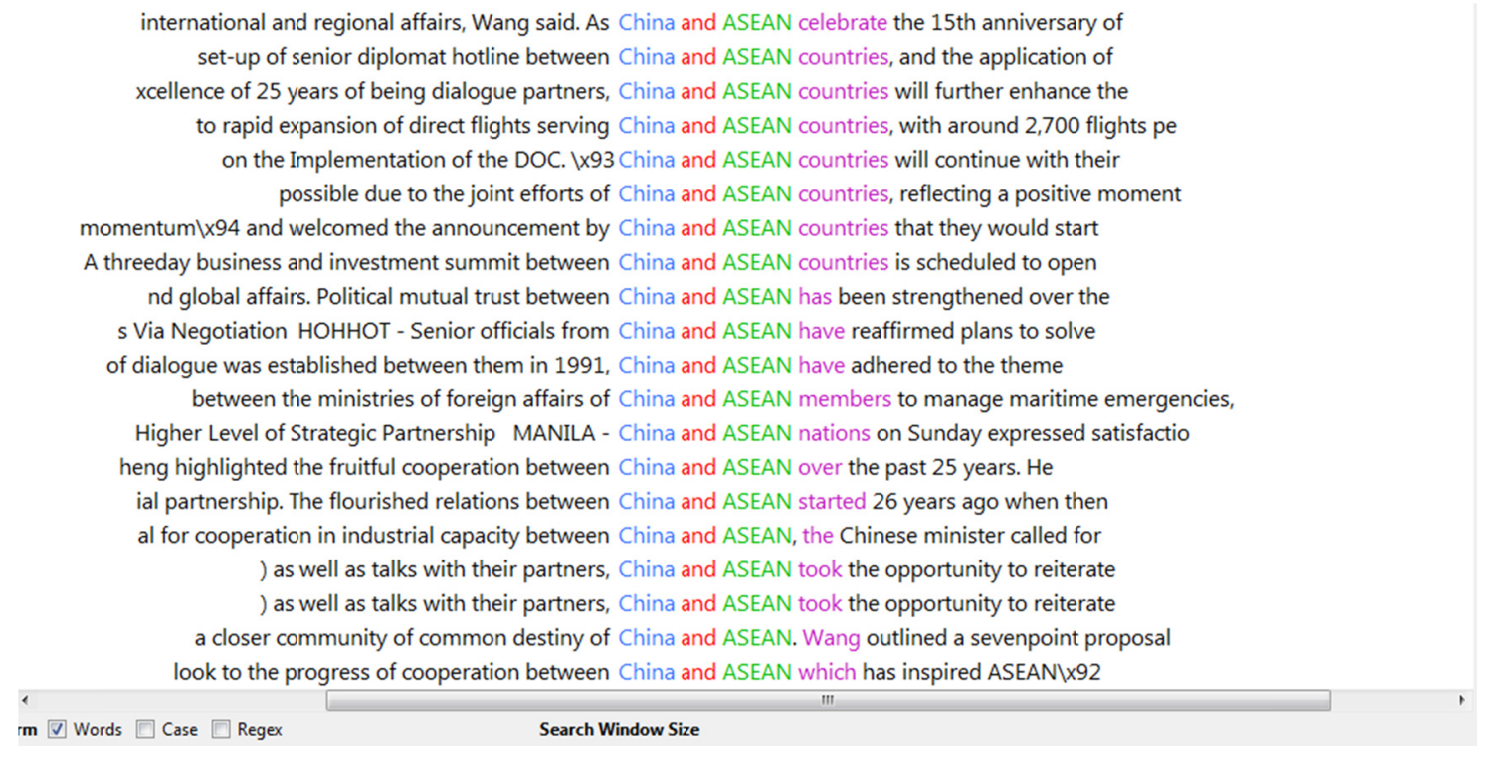

One of the extreme and repetitive patterns found in the concordance lines is the 'economy' of China as an ally, and a friend which helps in promoting and emerging the down economy of Afghanistan. Concordance 5 shows that the real picture in the newspaper data, which reveals that China is active in a friendly relation in terms of changing the policies to bring the economic changes in the country and sharing the Beijing's efforts in the development of Afghanistan.

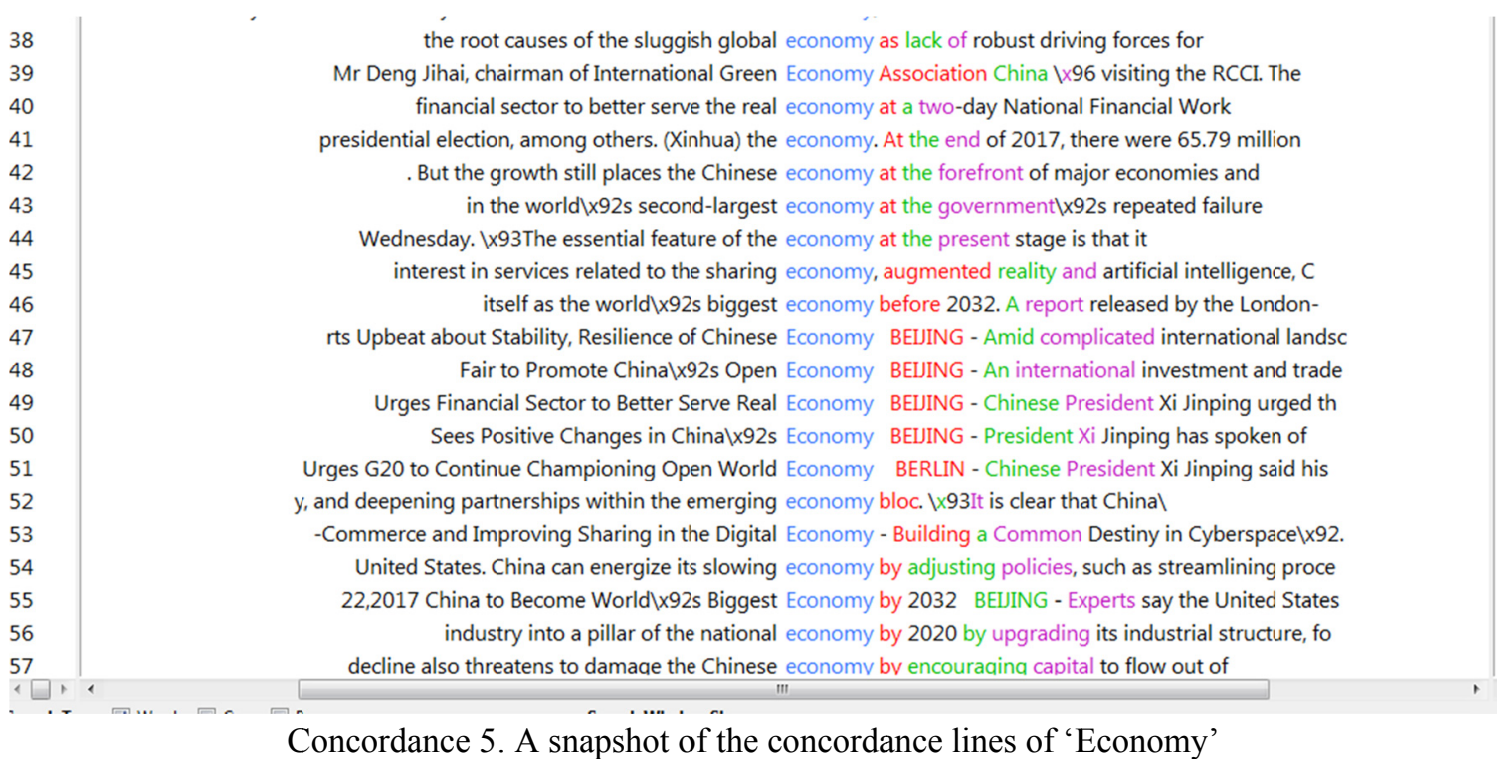

These repetitions of the economy are worth because it reveals the real intentions of China making ways to invest for the benefits of both the countries. In concordance 5, the foreign minister of China, makes a claim and repeats the friendly terms with Afghanistan to give an impression of trust for future friendly relations. Indeed, Fairclough (1989, p. 54) acknowledged that the hidden power of media discourse specifically in connection with repetition: 'a solitary text on its own is entirely insignificant: the influence of media abilities is accumulative, which means operating through the reiteration of special manners of handling relation and agency, particular method of placement the reviewer, and so forth.' As Baker (2010) pointed out, however, 'repetition is not the only requirement of a powerful discourse - the articulation of a new discourse, produced by a powerful speaker or writer may also be extremely influential,' such as a reiteration speech delivered by Bush (124). 


\begin{tabular}{|l|l}
142 \\
143 \\
144 \\
145 \\
146 \\
147 \\
148 \\
149 \\
150 \\
151 \\
152 \\
153 \\
154 \\
155 \\
156 \\
157 \\
158 \\
159 \\
160 \\
161
\end{tabular}

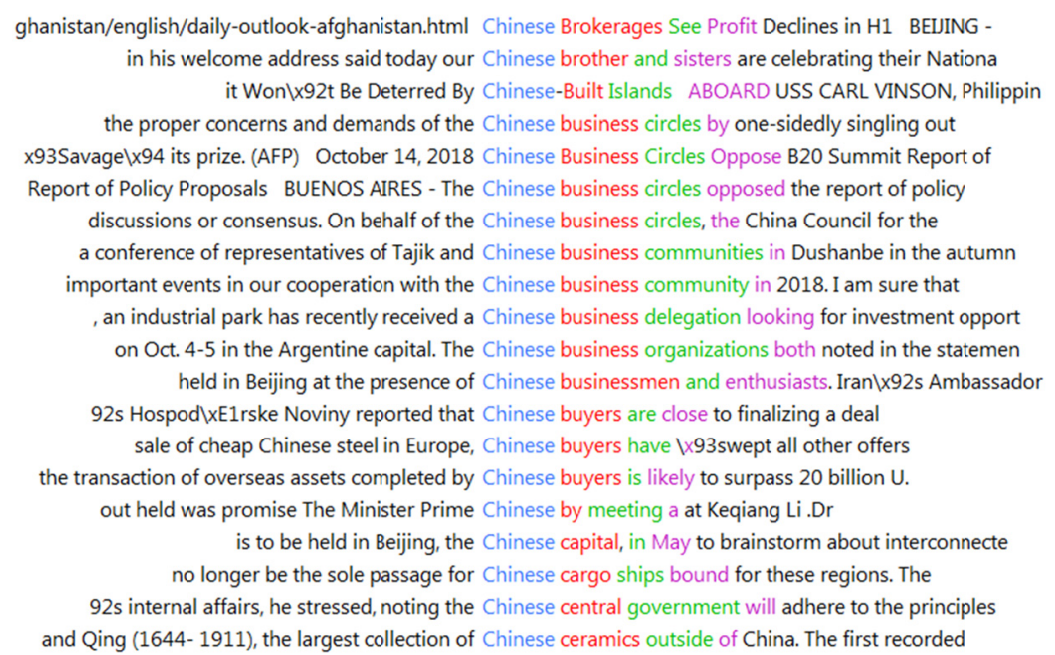

Concordance 6. Snapshot of Chinese business circle in Afghanistan

Sino-Afghan relations have been a long-lasting relationship based on political, economic, and diplomatic fronts. The relationship emerged in front of the world in 1955 when both the countries signed an economic treaty commonly known as the "Treaty of Economic and Technical Cooperation." The recent development in the trade, due to the economic rise of China around the globe, has given a new birth to the cooperativeness among the two countries. The current trade of China and Afghanistan has reached up to $\$ 700$ million between both the countries. The study, using the corpus-based analysis, shows this fact that the frequency of economic relations between Afghanistan and China has risen due to constructing significant trust and friendly relations with each other. The success in economic trade depends on the positive perspective of one's country in another.

\begin{tabular}{|c|c|c|c|}
\hline \multicolumn{4}{|c|}{ Concordance Hits 41} \\
\hline Hit & KWIC & & File \\
\hline 1 & & ation in various areas including trade, commerce, education and culture. Talking to Ambassador of China & Afghanistan \\
\hline 2 & & including but not limited to trade, culture, education and development cooperation. $\times 94$ \x93The relation & Afghanistan \\
\hline 3 & & jects including human development and livelihood, education and health. so that the benefits of & Afghanistan \\
\hline 4 & & elds such as trade, investment, finance, tourism, education and judiciary, economic cooperation is surely a & Afghanistan \\
\hline 5 & & covering aviation, energy, agriculture, culture, education and sports. France is facing a trade & Afghanistan \\
\hline 6 & & with enterprises and encourage social capital in education and talent training to adapt to the & Afghanistan \\
\hline 7 & & Tajikistan car have more exchanges in culture, education and youth, according to Xi. As rotating & Afghanistan \\
\hline 8 & & on machinery, information technology, culture and education are also being explored by the two & Afghanistan \\
\hline 9 & & chnology, Internet and communication, culture and education business and tourism, health and medication, and & Afghanistan \\
\hline 10 & & and local authorities further clarified. Regular education can help increase public awareness. Social and & Afghanistan \\
\hline 11 & & small and medium-sized enterprises and vocational education. China and Germany, both as the world $\backslash$ & Afghanistan \\
\hline 12 & & ts development plan. Capacity, infrastructure and education cooperation with countries under the Belt and & Afghanistan \\
\hline 13 & & in such areas as science and technology, education, culture and health,since the joint committee & Afghanistan \\
\hline 14 & & ountries Sign Agreements on Recognition of Higher Education Degrees BEIING - China has signed agreements o & Afghanistan \\
\hline 15 & & agreements on the mutual recognition of higher education degrees with $19 \mathrm{EU}$ member states, including Franc & Afghanistan \\
\hline 16 & & routes, while China $\backslash$ x 92 s Ministry of Education has inked over 60 deals with those countries. & Afghanistan \\
\hline 17 & & efforts to boost innovation and entrepreneurship education in colleges during an inspection tour in & Afghanistan \\
\hline 18 & & -afghanistan.html Xi Stresses Role of Higher Education in Fostering Talent BEIING - Chinese President & Afghanistan \\
\hline 19 & & S.organization that leads the Chinese language education initiative called $1 \times 931$ Million Strong.|x94 The 1 & Afghanistan \\
\hline 20 & & has asked the country $1 \times 92 \mathrm{~s}$ higher education institutes to ensure that graduates demonstrate $b$ & Afghanistan \\
\hline 1,1, & 1 & & $4 \pi$ \\
\hline
\end{tabular}

Concordance 7. A snapshot of the concordance lines 'education' 


\begin{tabular}{|c|c|c|c|}
\hline \multicolumn{2}{|c|}{ Concordance Hits } & & File \\
\hline 1 & & , water supply, sewage, the environment and green energy, according to a plan on Beijinglx92 & Afghanistan \\
\hline 2 & & rise in the capacity to generate clean energy, according to a latest study published by & Afghanistan \\
\hline 3 & & rise in the capacity to generate clean energy, according to a latest study published by & Afghanistan \\
\hline 4 & & r. Iranian ambassador to the International Atomic Energy Agency (IAEA) Reza Najafi told Xinhua the & Afghanistan \\
\hline 5 & & r. Iranian ambassador to the International Atomic Energy Agency (IAEA) Reza Najafi told Xinhua the & Afghanistan \\
\hline 6 & & envoy Monday called on the International Atomic Energy Agency (IAEA) to deepen cooperation on nuclear & Afghanistan \\
\hline 7 & & under the guidelines of the International Atonic Energy Agency. PM Nawaz said the Chashma-III & Afghanistan \\
\hline 8 & & witnessed the signing of deals covering aviaton, energy, agriculture, culture, education and sports. Fran & Afghanistan \\
\hline 9 & & than anyone in the world and pursuing energy alternatives faster than anyone in the world, $\backslash$ & Afghanistan \\
\hline 10 & & , with more to be done in transportation, energy, and border infrastructure development.(Xinhua) & Afghanistan \\
\hline 11 & & nd promote cooperation in areas including nuclear energy and electricity. (Xinhua) May 18,2016 http://pk & Afghanistan \\
\hline 12 & & ment BEUING - China will actively develop clean energy and improve energy efficiency to push green & Afghanistan \\
\hline 13 & & around th world, the development of nuclear energy and increasing use of nuclear technology in & Afghanistan \\
\hline 14 & & |x93very substantial amount $\mid \times 94$ of agricultural, energy and industrial products from the U.S. & Afghanistan \\
\hline 15 & & Harrington, the UK $\times 92$ s minister for energy and industry, said in a statement: $\mathrm{X} \times 93$ & Afghanistan \\
\hline 16 & & under the CPEC, which would help meet energy and infrastructure challenges being faced by Paki & Afghanistan \\
\hline 17 & & rtant security partner. Pakistan last year agreed energy and infrastructure projects worth $\$ 46$ billion wit & Afghanistan \\
\hline 18 & & . He noted that project related to $\mathrm{CPEC}$, energy and infrastructure were progressing smoothly and & Afghanistan \\
\hline 19 & & Agency (IAEA) to deepen cooperation on nuclear energy and nuclear technology and further increase its & Afghanistan \\
\hline 20 & & oad through improving transport, infrastructures, energy and other forms of cooperation. The meeting & Afghanistan \\
\hline
\end{tabular}

Concordance 8. A snapshot of the concordance lines 'energy'

\begin{tabular}{|c|c|c|c|}
\hline \multicolumn{2}{|c|}{ Concordance Hits } & & File \\
\hline 1 & & directed the ministry to prepare initiatives on Afghanistan and also on building economic and trade & Afghanistan \\
\hline 2 & & said there are also opportunities for Iran, Afghanistan and Central Asia. (Xinhua August 04,2016 http:/ & Afghanistan \\
\hline 3 & & eastern end of Tajikistan that borcers both Afghanistan and China. Tajikistan $\backslash x 92$ s Ministry of & Afghanistan \\
\hline 4 & & eastern end of Tajikistan that borcers both Afghanistan and China. Tajikistan $x 92 \mathrm{~s}$ Ministry of & Afghanistan \\
\hline 5 & & militant groups in Pakistan and concerns of Afghanistan and India. While Mr. Lu did not & Afghanistan \\
\hline 6 & & projects will be later expanded to neighboring Afghanistan and Iran, he said. (Xinhua) November 09,2016 Pak & Afghanistan \\
\hline 8 & & Ix92s increasing concern about instability in Afghanistan and the capacity of other regional countries & Afghanistan \\
\hline 9 & & X92s increasing concern about instability in Afghanistan and the capacity of other regional countries & Afghanistan \\
\hline 10 & & romote the security, stability and development of Afghanistan and the region, $\mathrm{x} 94$ Hua said. (Monitoring & Afghanistan \\
\hline 11 & & urged to promote security and stability in Afghanistan and the region XX93to createa community & Afghanistan \\
\hline 12 & & stability and economic and social development in Afghanistan and the region to create a community & Afghanistan \\
\hline 13 & & amid mounting pressure on Islamabad from India, Afghanistan and the United States to rein in & Afghanistan \\
\hline
\end{tabular}

Concordance 9. A snapshot of the concordance lines 'Afghanistan'

\begin{tabular}{|c|c|c|c|}
\hline \multicolumn{2}{|c|}{ Concordance Hits } & & \multirow[b]{2}{*}{ File } \\
\hline Hit & KWIC & & \\
\hline 1 & & commission for cooperation in the field of science and innovative technologies. The forum was attend & Afghanistan \\
\hline 2 & & research associate with the Belfer Center for Science and International Affairs at Harvard University. & Afghanistan \\
\hline 3 & & ks while inspecting China University of Political Science and Law ahead of Youth Day, which & Afghanistan \\
\hline 4 & & the countries of Central Asia on innovations, science and technologies. (Trend) October 28, 2018 Fran & Afghanistan \\
\hline 5 & & Hubei, Liu also visited Huazhong University of Science and Technology and Wuhan University, stressing th & Afghanistan \\
\hline 6 & & cohosted by Chinalx92s Ministry of Science and Technology and the Ministry of Economic & Afghanistan \\
\hline 7 & & example, embraced innovation $\backslash x 93$ by incorporating science and technology, and linking academia to the & Afghanistan \\
\hline 8 & & s-- discipline inspection, politics and law, and science and technology -- as well as the general & Afghanistan \\
\hline 9 & & between Iran and China in politics, economy, science and technology as well as culture. $1 \times 93$ & Afghanistan \\
\hline 10 & & (18) October 11,2016 China Calls for Reform of Science and Technology Associations BEIING - Science an & Afghanistan \\
\hline 11 & & of Science and Technology Associations BEIING - Science and technology associations in China should bette & Afghanistan \\
\hline 12 & & ed Press. Shi said manufacturer Chinese Aerospace Science and Technology Corporation plans to test fly & Afghanistan \\
\hline 13 & & bilateral pragmatic cooperation in such areas as science and technology, education, culture and health,sin & Afghanistan \\
\hline 14 & & the Development Strategy Center and the Shanghai Science and Technology Exchange Center (SSTEC) at the & Afghanistan \\
\hline 15 & & and established a compara tively complete nuclear science and technology industry system. The peaceful use & Afghanistan \\
\hline 16 & & the exchange of talented young people in science and technology industry. Following the summit, a & Afghanistan \\
\hline 17 & & with New Zealand in such areas as science and technology, innovation, agriculture, livestoc & Afghanistan \\
\hline 18 & & for May 28 to June 1 , will focus on science and technology, Internet and communication, cultu & Afghanistan \\
\hline 19 & & attended by representatives of the Ministry of Science and Technology of China, Department of Science & Afghanistan \\
\hline 20 & & Science and Technology of China, Department of Science and Technology of the Chinese provinces of & Afghanistan \\
\hline
\end{tabular}

Concordance 10. A snapshot of the concordance lines 'Science and Technology' 
Snapshots $7-10$ of the corpus reveal the investment and interest of China in Afghanistan while focusing on the future friendly relations goals and economic stability of both countries, particularly in the region countries in general. The overall image that is constructed through the concordances of the corpus such as concordances, "Science and Technology," 'energy,' Afghanistan,' and 'education' express the positive relationship of China with Afghanistan. Also, keywords occurring in the data show a significant positive construction of the image of China in Afghanistan. The headlines in the newspaper, such as 'China as an economic tiger of Asia,' Science and Technology predict the macrostructure of construction of Chinese interest in economic stability. The frequent occurrences of infrastructure and energy in the corpus news show the keen interest and current engagements of two governments' collaboration for development, which would be an initial step in the development of the region.

\section{Discussions}

The study aimed to explore the analysis of newspapers based on the image of China in the Afghanistan Outlook English newspaper. The results are presented in previous sections; the detailed discussion on the results is given here. The perception of China is quite better, which can be traced through the statistical analysis of the keyword 'country' in the entire data. Chinese companies have been exploring new positions and platforms to invest in economic assistance, and the Chinese government has provided Afghanistan an offer to build a power plant. A railway road to build the infrastructure of Afghanistan will definitely increase the relationships and investments in more significant numbers.

While probing into the detail qualitative analysis, the speech of Chinese and Afghan leaders for the promotion of their relationships, the text shows a significant positive friendship based on cooperation, economic ties, and business trades. For instance, Chinese foreign minister Wang Yi discusses the economic cooperation in his interview as "Next year, Afghanistan would celebrate its 100th Independence Day, and a peaceful settlement of the conflict by then would be a good gift for the Afghans who have suffered for up to 40 years of war and instability" (Outlook, Dec 2017). The lexical choice in his speech shows a great depth of understanding, such as 'peaceful,' settlement, which also presents the notion that China wants a friendly relation even for the development and settlement of the broken economy of Afghanistan.

On another occasion, the massive investments by Chinese have explored the correct nature of China, while making the relationship stronger. Shahrvand (2017) argues, in his report in the newspaper, that China has a good image politically in Afghanistan, as China continuously develops political development in Afghanistan and favors its independence and sovereignty, and actively promotes political reconciliation there. Furthermore, it reported that the People's Republic of China, along with its widespread economic activities, has always stepped up its efforts to strengthen the security and defense capabilities of the Afghan security sector through scholarships and educational trips. For instance, it mentioned that the recent visit of the senior consultants of the Ministry of Interior to China has raised their awareness, skills, vitality, and spirits.

Besides, China has initiated a considerable investment in the 'One Belt and One Road' (OBOR) project to connect, for the economic stability of the world, the region and China together. At the same time, OBOR has also provided a chance for China to improve the relations with its neighboring countries based on cross-cultural cooperation, language promotion, and the development and also for the prosperity of the region. President of Afghanistan explained the relationship between China and Afghanistan as 'I believe that political and economic borders should split up in order the regional people can use the economic capacities in the best way.' Kabul supports the OBOR project in Afghanistan's soil because it would not only help Afghanistan to develop domestically, but it will also improve relations between these two countries and other regional countries.

However, such kind of diplomatic relations was established between the two neighbors in 1955. Chinese Prime Minister, Mr. Zhou Enlai, came to Afghanistan in 1957 during the Cold war era. Earlier, Daud Khan, the Prime Minister of Afghanistan, visited Peking, capital of China, in the same season of the year. Therefore, these kinds of visits established the mutual relations among the two republics. However, China suspended her formal relations with Afghanistan amidst the Soviet Union and, after the fall of the Taliban leadership, China restored relations quickly in 2001. Since then, the Sino-Afghan relations have changed and developed. Lately, bilateral meetings and high-level diplomatic meetings have held several times. Since last time, the Chinese Foreign Minister, State Councilor, and Chief of General Staff Deputy visited Afghanistan individually.

Thus, it is the first event in history that these several Chinese leaders' visits have happened to Afghanistan in a duration of a one year. Within doors, the territorial circumstances, Afghanistan's friendship with China are presumably comprehended very desirably, both in duration of the continuing transformation period and the post-2014 situation, including a growing marketplace though grants which they will perform a decisive role in 
Afghanistan and in the region because China is the only predictable relevant territorial country to do that. On another side, Afghanistan can grant China the most natural transport way for exploration of energy and mineral resources inside Afghanistan and its adjoining region as well as the Caucasus and Central Asia. Furthermore, currently, thousands of Afghan civilians, as of now, got visas to visit China to obtain excellent opportunities for commerce and trade.

Therefore, in an extension of this, hundreds of Chinese civilians live and operate in different work fields in Afghanistan. In identical circumstances, Gray (2013) observes that there are rare amongst the players in Afghanistan in which they are not comprehended while having been extremely private to any part of the battle. Moreover, all parts are pleased to see China's increased role in Afghanistan. China has had a balanced relation with almost all the Afghan ethnic groups and, therefore, has not favored any particular groups against the other. Likewise, Wadsam (2013) views that China is the only country that can increase the level of investments in the economy of Afghanistan which demands to stick it out and make it succeed.

\section{Conclusion}

The study aimed to understand the image of China in the Afghanistan Outlook English newspaper. The study identifies a real positive perspective of China in Afghanistan. The keywords, concordances, and collocations of searched items in the corpus, the contextual relevance of China, and the occurrences of most repeated patterns in the primary data reveal a positive image in discourses of Afghanistan. The strategic location of Afghanistan, the market exploration, and the economic assistance of China towards Afghanistan have marked a significant factor in the promotion of China's rise and an image of a true friend instead of an economic rival. The massive investment in oil exploration, business markets, minerals, and the energy sector is the true need of both two countries.

Therefore, the study concludes that Afghanistan desires a kind and friendly relations with China to bring stability for Afghanistan, and economic benefits and achievements through the development and building infrastructure, and economic hubs by means of the Eurasia project. The scope of this investigation is to get information concerning China's image in the position of Outlook English newspaper in Afghanistan.

Therefore, the study shows a clear perspective on both countries' current and old real relations. Furthermore, the significance of conducting this research determines a generic reflection of China in Afghanistan Outlook English newspaper. Afghanistan and China have enjoyed good relations for many years, whereas official diplomatic ties between the two countries accepted in January 1955, China and Afghanistan cooperated on different occasions, and strongly constructed their relations. China and Afghanistan signed many agreements. Therefore, the relations between China and Afghanistan have been close with friendly contact during all periods.

The study takes the image of China in the Afghanistan Outlook English newspaper; However, by focusing on the newspaper discourses, this paper provides a real insight to analyzing the newspaper construction of ideology and image through merging of the corpus-based studies into the theoretical framework of critical discourse analysis. Finally, the analysis of collocation, keywords and concordances shows China as an economic and strategic partner of Afghanistan.

\section{References}

Baker, P. (2006). Using Corpora in Discourse Analysis. London: Continuum.

Baker P. (2010). Sociolinguistics and Corpus Linguistics. Edinburgh: Edinburgh University Press.

Baker, P., Gabrielatos, C., Khosravinik, M., Krzyanowski, M., McEnery, T., \& Wodak, R. (2008). A useful methodological synergy? Combining critical discourse analysis and corpus linguistics to examine discourses of refugees and asylum seekers in the UK press. Discourse and Society, 19(3), 273-306. https://doi.org/10.1177/0957926508088962

Boulding, K. E. (1966). The Image: Knowledge in Life and Society. Ann Arbor: University of Michigan Press.

Buchanan, W., \& Cantril, H. (1953). How Nations See Each Other. Urbana: University of Illinois Press.

Crespi, L. P. (1961). Some observations on the Concept of Image. Public Opinion Quarterly, 25, 115-120. https://doi.org/10.1086/267000

Fairclough, N. (1989), Language and Power (p. 259). New York: Longman.

Fairclough, N. (1992). Discourse and Social Change. Cambridge: Polity Press.

Fairclough, N. (1995). Critical discourse analysis: Papers in the critical study of language. New York, NY: Longman. 
Fairclough, N., \& Wodak, R. (1997). Critical discourse analysis. In T. A. van Dijk (Ed.), Discourse as social interaction (pp. 258-284). London, England: Thousand Oaks.

Flowerdew, J., \& Miller, L. (2005). Second language listening: Theory and practice. Cambridge University Press.

Fowler, R. (1991). Languages in the News: Discourse and Ideology in the Press. London and New York: Routledge.

Gary. (2013, January 30). Afghanistan, First Russia, then the USA, Next China. Retrieved from http://www.notsosilentthoughts.com/2013_01_01_archive.html

Gheisari, A., Shahrvand, S., \& Landy, N. (2017). Effect of ethanolic extract of ropolis as an alternative to antibiotics as a growth promoter on broiler performance, serum biochemistry, and immune responses. Veterinary World, 10(2), 249. https://doi.org/10.14202/vetworld.2017.249-254

Hardt-Mautner, G. (1995). Only connect: Critical discourse analysis and corpus linguistics. UCREL Technical paper 6. Retrieved December 27, 2013, from http://stig.lancs.ac.uk/papers/techpaper/vol6.pdf

Huang, Y., \& Leung, C. C. M. (2005). Western-Led Press Coverage of Mainland China and Vietnam during the SARS Crisis: Reassessing the Concept of 'Media Representation of the Other'. Asian Journal of Communication, 15(3), 302-318. https://doi.org/10.1080/01292980500261621

Lippmann, W. (1945). Public Opinion. New York: Macmillan Publishing Co.

Mautner, G. (2009). Corpora and critical discourse analysis. In P. Baker (Ed.), Contemporary corpus linguistics (pp. 32-46). New York, NY: Continuum.

Orpin, D. (2005). Corpus Linguistics and Critical Discourse Analysis: Examining the ideology of sleaze. International Journal of Corpus Linguistics, 10(1), 37-61. https://doi.org/10.1075/ijcl.10.1.03orp

Peng, Z. (2004). Representation of China: An across time analysis of coverage in the New York Times and Los Angeles Times. Asian Journal of Communication, 14(1), 53-67. https://doi.org/10.1080/0129298042000195170

Prentice, S., \& Hardie, A. (2009). Empowerment and disempowerment in the Glencairn Uprising: A corpus-based critical analysis of early modern English news discourse. Journal of Historical Pragmatics, 10(1), 23. https://doi.org/10.1075/jhp.10.1.03pre

Quratul, A., \& Imran, M. (2019). Effects of Non-Native Instructors' L1, Beliefs and Priorities on Pronunciation Pedagogy at Secondary Level in District Rajanpur, Pakistan. Journal of Language and Cultural Education, $7(2), 108-121$.

Rafique, N., Sultan, B., Ahmad, S., \& Imran, M. (2018). Teachers' Role in Implementation of English Language Teaching Policies in Public Primary Schools of Rural Area in Punjab, Pakistan. Language in India, 18(4), $252-260$.

Salama, A. H. Y. (2011). Ideological collocation and the recontextualization of Wahhabi-Saudi Islam post-9/11: A synergy of corpus linguistics and critical discourse analysis. Discourse \& Society, 22(3), 315-342. https://doi.org/10.1177/0957926510395445

Stubbs, M. (1996). Text and Corpus Analysis. Oxford: Blackwell.

Swales, J. M. (2002). Integrated and fragmented worlds: EAP materials and corpus linguistics. Academic Discourse, 150-164.

Teubert, W. (2007). Natural and Human Rights, Work and Property in the Discourse of Catholic Social Doctrine.

Tognini-Bonelli, E. (2004). Working with Corpora: Issues and Insights. In C. Coffin, A. Hewings \& K. O’Halloran (Eds.), Applying English Grammar.

Tolson, A. (1996). Mediations: Text and Discourse in Media Studies. London: Arnold.

Van Dijk, T. A. (1988). News as discourse. Hillsdale, NJ: Lawrence Erlbaum Associates.

Van Dijk, T. A. (1998). Ideology: A Multidisciplinary Approach.

Wadsam. (2013, January 27). China has its Eyes on Afghanistan's Minerals, Afghan Business News Portal. Retrieved

from

http://wadsam.com/afghan-business-news/china-has-its-eyes-on-afghanistans-minerals-2342/ 


\section{Copyrights}

Copyright for this article is retained by the author, with first publication rights granted to the journal.

This is an open-access article distributed under the terms and conditions of the Creative Commons Attribution license (http://creativecommons.org/licenses/by/4.0/). 